Article

\title{
American Muslim Character Cancellation: Framing Engagement through the Sphere of Deviance
}

\author{
Jibril Latif \\ Department of Mass Communications and Media, Gulf University for Science and Technology, 32093 Hawally, Kuwait; \\ E-Mail: latif.j@gust.edu.kw
}

Submitted: 10 April 2020 | Accepted: 31 May 2020 | Published: 15 October 2020

\begin{abstract}
While freedom of religion is constitutionally safeguarded in the United States, practice and expression thereof are modulated by apparatuses exhorting both ethnic and faith communities to flatten into expedient caricatures. The 'moderate Muslim' caricature is contingently acknowledged as a victim of animus thereby expected to unquestioningly advance state objectives. American Muslim scholars consequentially maintain a vigilant wariness of state engagement, sentiments further intensified when Donald Trump came to power. With the Trump regime's perilous track record, Muslims willing to engage the federal government during the initial term were expectedly criticized. Situating the American Muslim communal consultation process (al-shūrā), this article analyzes 100 opinion editorials responding to the Department of State's formation of the Commission on Unalienable Rights in 2019, and its inclusion of a recognizable Muslim scholar as commissioner. For disparate reasons, editorials authored by critical communal voices formulated a perceived consensus against any engagement with the regime whatsoever, suggesting self-censoring expressive parameters and balkanization. Using Daniel Hallin's sphere of deviance, findings indicate that amidst increased expectations for religious leaders to be more accessible and accommodating, communal consultation on political issues broke down in the virtual spaces the scholar's critics inhabited whilst his own public relations messaging operated with discernable ambivalence. Findings further suggest that as American Muslims increasingly identify with the social justice language of the far-left, communal thought leaders' racial, ethnic and cultural backgrounds disproportionately factor into how their words and engagements are interpreted and tolerated.
\end{abstract}

\section{Keywords}

American Muslim; Arab media; balkanization; cancel culture; media framing

\section{Issue}

This article is part of the issue "Freedom of Expression, Democratic Discourse and the Social Media" edited by Maria Elliot (Linnaeus University, Sweden) and Kristoffer Holt (Linnaeus University, Sweden).

(C) 2020 by the author; licensee Cogitatio (Lisbon, Portugal). This article is licensed under a Creative Commons Attribution 4.0 International License (CC BY).

\section{Transcending Black and White Discourse Boundaries}

During comedy sketches, Dave Chapelle can wantonly use the $\mathrm{N}$-word with seemingly unlimited license. In fact, wielding it as a prop he generates ample laughter and applause from white audiences allowed to laugh, but never allowed to retell. When Chappelle's 2019 Netflix special Sticks \& Stones was initially awarded a $0 \%$ rating on Rotten Tomatoes because progressive critics with exclusive voting rights were offended by his risqué jokes on the social accommodation of mutable sexuality as iden- tity in which he called gender dysphoria crazy, under the aegis of their rubric, Chappelle was being labeled a deviant (Hasan, 2019). Is the $\mathrm{N}$-word tolerable whilst conventional appraisal of gender ideology is not? Luckily for Chappelle, it was a hurdle overcome in irony once 40,000 audience members were allowed to democratize the audience rating, shooting the score up to $99 \%$ overnight (Hasan, 2019). This anecdote suggests that the rubric governing discourse parameters disproportionately arbitrates these peculiar and distinct freedoms of expression. How much are these licenses rooted in shifting 
moralities and views of history? Could Chapelle have as narrowly escaped cancellation if his critique had been openly informed by his private personal conviction in Islam? Philosopher Christopher Tollefsen makes a similar critique about gender dysphoria without the punchlines, using the slightly more benign and clinical word choices "mental illness" and "pathology," but detractors almost inextricably cite his identity markers-white, male and Christian-in ad hominem rebuttals against Tollefson's arguments for sensible traditional morality in society (Tollefsen, 2015). Therefore, it seems identification as an oppressed minority wields a pathos-laden license not necessarily extended to an individual who identifies with the truth claims of his or her religion, and vice versa. In such an environment, theologians guarding tradition must tread carefully. This sentiment echoes when a wellrecognized American Muslim theologian and public intellectual, Shaykh Hamza Yusuf Hanson, tells a largely Christian audience at the Field Museum in Chicago during philosopher Alvin Plantinga's retirement celebration:

Given the suspicion, even the disdain among a lot of intellectual and educated people about theology, I sometimes hesitate when people ask me 'what do you teach?' to say theology because it's a little bit like saying I practice alchemy or I study unicorns. (Hanson, 2017)

Awkward boundaries function as discourse markers that influence and govern our ever-shifting freedoms of expression in public and communal spaces, and exploring them alerts us to the expected societal recourse of who can say what from which epistemic perspective. Throughout history, many have been allowed to conveniently dismiss how America's original sins of genocide and racial oppression still impact present-day expressive boundaries, but the filming and media circulation of extrajudicial police killings in 2020 brought about another round of protests and uncomfortable national discussions on racial ideology. Back in the 1990s, a time when black Americans would often change their names with zeal after converting to Islam, in both a cognitive disassociation to the name of their ancestors' slave-owners and the liberation that self-identification establishes, basketball star Chris Jackson became Mahmoud Abdul-Rauf mid-career. Citing his religious understanding as the basis for his refusal to stand for the National Anthem, his right to free speech was, ostensibly, legally protected, yet he was consequentially framed in the media as an unpatriotic ingrate who had committed the seditious act of becoming Muslim; he received death threats, had his home burned to the ground, and found himself out of the league in short order despite being one of the alltime great shooters (Chopra, 2018). In more recent times, the sports figure Colin Kaepernick similarly attempted such a protest and found himself out of football thereafter. We can similarly intuit what the outrage would have been if Kaepernick-who is biracial, but consid- ered black in the United States-linked his cause to a public commitment to Islam. Despite expressed desire to keep his personal convictions a private matter, the dark web similarly labeled him a Muslim for having a Muslim companion. How can we better understand this? For one, the label Muslim has served as an epithet since the country's founding, and while Muslims are generally bound by theology, the antecedents of race in America have fluidly moved discursively between religion, culture and biology (Milani, 2014). Moreover, in the current zeitgeist, pervasive anti-Muslim sentiments enable the media and political apparatuses to regularly flatten Muslims into inescapable caricatures. State-funded initiatives, like the controversial Countering Violent Extremism program and its documented history of entrapment, suggest that good and moderate Muslims are to assume essentializing roles as contingently protected victims of Muslim animus thereby expected to unquestioningly aid the state in problematic initiatives (Shaikh, 2019).

Islam is still the fastest growing religion in the country, especially in downtrodden communities and prisons, with estimates wildly ranging from 3 to 15 million adherents, but because of its associated social stigma many American Muslims understandably keep their religious commitments sequestered, woefully leaving the abject caricatures unchallenged (Lipka, 2017). Consequentially, this all serves to perpetuate the privation of American Muslim social capital in the public sphere. President Barack Obama-another Christian epithetically tagged as Muslim-affirmed that "Muslim-Americans are our friends and our neighbors, our co-workers, our sports heroes," to which Donald Trump responded on Twitter: "Obama said in his speech that Muslims are our sports heroes. What sport is he talking about, and who? Is Obama profiling?" (Borchers, 2015). During his 2016 candidacy, Trump politically mobilized festering Muslim animus with sophistic pronouncements such as "Islam hates us" and once in office, the rhetoric and policies proved unremitting. Despite his conceptual usage being consistently and vapidly incorrect, as Islam is not a proper noun, Trump's demagogic ploys framed Muslims with a diminution of dignity that may be likened to what has been perpetuated against the black community. Although likening one grievance to another typically portends fallacious reasoning, evidenced by intersectional movements that appropriate the history of racial struggles to advance ideological agendas on gender and sexuality, it is critical to refrain from summarily dismissing how the combination of racial and religious identities work in the American context where unapologetic and dynamic black American Muslims like Malcolm X, Muhammad Ali, Warith Deen Mohammed and Kareem Abdul-Jabbar brought Islam into the American consciousness. It is both an epic tale of how hard-fought social capital was gained and also a tragic tale of how it was thereafter squandered, a situation aggravated by intercommunal contestation over authority tied to race. Timothy Daniels (2019, p. 66) frames abiding intercommunal tensions as a lack 
of "respectful and principled relationships" between indigenous and immigrant communities, acknowledging a binary in how black American Muslims were supplanted in representation and authority by immigrant Muslim communities that appeared in large numbers after immigration reform in 1965; it is the thesis Sherman Jackson (2005) has outlined, an evolution of frayed relationships as binary chronologies critical to understanding the cultural and ideological trajectories of today's fragmentation. Jackson further argues that irreconciliation with black suffering abides as a key issue of contestation on authority amongst American Muslims (Jackson, 2009).

Nevertheless, as miscegenation and indigenization occur, black and white boundaries become less able to provide a totalizing picture of today's communal dynamics. Ideology and first principles more appropriately explain that division. While a few Muslims do receive coverage in the public sphere, the obscured caveat is that they must almost exclusively use the framework laid down by political progressives, exemplified by the sneering political satire Netflix allows Hasan Minhaj, the smutty comedy Hulu allows Ramy, or the conditional advocacy the far-left offers Linda Sarsour's version of intersectional activism. In juxtaposition, Hanson operates within a classical anti-nominalist perspective that affirms traditional realities now deemed offensive to some, such as hierarchies, while maintaining a voracious reading appetite akin to the late Harold Bloom's and a honed gift of persuasive oratory that combines vast amounts of seemingly disparate perspectives into theological sermons. It was this generational ability that catapulted him into the public spotlight in the 1990s. For brevity, we can pinpoint one encapsulating example from 2004, when Hanson spoke in front of Shakespearean scholars at London's Globe Theatre and proposed an anagogical reading of Othello's lago as Santiago de Mato Moros (James the Moor slayer), the personification of evil as Conquistadores who had driven Muslims out of Spain instead of promoting La Convivencia (coexistence). Culturally attenuated erudition able to offer metaphysical conceits and new readings of Shakespeare, whilst also masterfully navigating the Qur'an, is a rare ascent that impresses many westerners, especially Muslims. However, there are both opportunities and perils in how this capacity resonates with non-Muslim audiences comprised largely of white, Christian conservatives with elite educations who welcome a moderate presentation that amalgamates east and west out of a shared concern for the plight of traditional mores in society, and the encroachment of secularism. Naturally, when philosopher Alvin Plantiga's retirement ceremony was hosted by the John Templeton foundation in 2017, Hanson was selected as perhaps the solitary Muslim scholar qualified to deliver an address acknowledging Plantiga's contributions and those of other Christian philosophers like G. K. Chesterton, another encapsulation reinforcing why he is celebrated in conservative circles for arguing the continued relevance of reasonable faith in the public sphere:
People today...glibly dismiss belief in God as inherently unreasonable, and yet they'll say 'I don't believe in God' without ever looking at some of the arguments. The same people, however, will believe in things like quarks and neutrinos; they'll believe in dark matter and they won't know the science that substantiates belief in those things. They simply trust the scientists that believe in such phenomena that we can't see. We have theologians also that have their arguments for believing in the things that they don't see. Just like most people believe in scientists without really knowing their proofs, many believers, simple people, believe what their teachers and their philosophers tell them without having their proofs. So, we forget that the age of science is also an age of faith. Just like the age of faith, was actually also an age of science. And, something that we forget is that the epistemology of trust is foundational in our world. (Hanson, 2017)

In 2019, Hanson was appointed as a commissioner on the Department of State's Commission on Unalienable Rights, which convened under the aegis of President Trump's Secretary of State, Mike Pompeo. The engagement was controversial to American Muslims who are generally split on how to value contingent acknowledgment from the dominant culture. Because no matter how assimilated or integrated descendants of Muslim immigrants become, Shakespeare cannot become part of their cultural heritage; moreover, critical voices argue that they should check the impulse present among communal members who myopically seek asymmetrical validation, questioning whether it is worth their community's top scholars having to, as they see it, fit the mold of a conservative Catholic theologian in order to sit at the table. Unquestionably, some are ultracrepidarians with axes to grind, however, others comprise former supporters and donors perplexed by the optics of recent engagements with no real access to dialogue or nuanced explanation. Indicating a perceived communal consensus against engagement with the Trump administration, vocal critics found a synergy on the issue despite promoting disparate ends. In that light, this article examines shifting boundaries of expression as they pertain to the American Muslim community by surveying opinion editorials written in response to Hanson's appointment.

\section{Interpretive Audiences: Trained and Untrained Interpreters}

In the study of religions, an important distinction exists in the bifurcation of the normative and descriptive approaches. As authoritative interpreters of normative tradition, theologians must equip themselves with the tools needed for navigating scriptures and communicating them effectively to audiences. What modern audiences in turn do with such messages as they are filtered through cultural matrices is perhaps more indicative of 
culture than intrinsic representation of Islam itself. For centuries, Muslims have congregated in sacred spaces while observing hierarchical dynamics deferentially binding congregants to scholars in acknowledgment that intellect and decades of demanding training in the tradition, its scripture and concomitant sacerdotal languages, its spiritual sciences, and its sacred law are prerequisites that deem scholars esteemed inheritors of the prophets. On the other hand, Muslims emphasize scholarly fallibility and engage in consultative interaction (al-shūrā) in a symbiosis that forces scholars to attenuate their diktats to each zeitgeist. Epistemically, of course, there are differences between the first principles and processes that dominate western-conceptualized democratic processes, but researchers have also noted tremendous overlaps (Bulliet, 2004).

In the classical context, an archetypal Muslim scholar was an erudite polymath possessing the advantages of access to knowledge, rarefied mastery, and the freedom to offer declarative statements with little fear of reprisal due to the financial and political independence the waqf endowment system provided. Such myriad advantages very often precluded the possibility of decentering dialogues between lay congregants and scholars, whereas today widespread functional literacy and the diffuse proliferation of knowledge perplex theologians who thereby struggle to maintain the primacy of religious scripture amid rapidly changing societal norms. In the traditional Muslim world, post-colonial traumas have contributed to a concomitant communal crisis of authority and ethics. As a result, Muslim scholars today are largely politically snarled and financially hamstrung (Tripp, 2006). The distinctive emergent perceptions complicate American Muslim dynamics when those from the traditional Muslim world arrive on America's shores and interject post-colonial notions of Islam and politics into local discussions in unawareness of complex local histories.

Furthermore, the blurring of lines between laity and scholarship allows for the unqualified to maintain platforms feigning as authorities, a decentering that social media heavily exacerbates. Online influencers, community activists, and woke Muslims trained in secular critical methods, yearning for certain progressive readings of scripture, seek to expeditiously democratize interpretation in ways that displace the role of traditional scholarship. Analogously, reader response theory popularized by Stanley Fish (2001) has recently dominated the interpretive landscape of poetry; hence, to read John Milton in a university class is often to read through a heuristic lens that similarly decenters authorial intent and meaning. John Mullan (2001) points out how it is neither impartial nor insignificant that Fish's coterie declares "no principles" or that "there is no truth, only fancy argument," and questions why readers should accept guides that unrelentingly aim at wrestling texts to their own cause. Correspondingly, interpretive religious scholars are increasingly reduced to ceremonial conductors of weddings or funerals and told to stay in their lane and out of secular life, especially politics.

\section{Shifting Political Consensus}

A shifting political consensus also disfavors the licenses of expression extended to theologians because American Muslims were principally political conservatives before 9/11, whereas a stagger leftward was thereafter engendered by the copious presence of anti-Muslim ideologies on the right such as neoconservatism and Zionism, and the perceptibly higher levels of external empathy and accommodation displayed by some on the left. Thus, today most American Muslims self-identify as principally liberal even though a practicing Muslim has more shared virtue interests with traditional conservatism (Mogahed \& Chouhoud, 2017). The Economist ("Why American Muslims," 2019) observes the end of a time when nearly $50 \%$ of votes went to Republicans (now 11\%), and the patterned emergence of progressive Muslim politicians like Keith Ellison, Rashida Tlaib, and Ilhan Omar as a reflection of shifting ideological landscapes. Muslims now mostly lean towards the most far-left wing of the Democratic Party. In contrast, Hanson chooses to dialogue with embattled conservatives who-like the late Roger Scruton-espouse conservatism as looking first at what is right in the world and setting out to conserve it, rather than seeking out first what is wrong in the world and endeavoring to fix it. Both readings have their textual support from exegetical commentaries, but what appears rare about this particular age is the disappearance of a line that opposing communal parties agree not to cross out of respect, where attacks do not become malicious or personal. Hanson, who co-founded Zaytuna College with Zaid Shakir and Hatim Bazian, was acknowledged for a long duration as the most influential scholar of Islam in the west, but as communities adopt different visions of the world, influence shifts. For instance, in both 2016 and 2020 the Los Angeles Times covered the remarkable American Muslim support for progressive Senator Bernie Sanders, citing Imam Omar Suleiman, a voice for activist-minded adherents that prioritizes their specific political concerns: "Muslims are progressive on issues like healthcare, immigration, criminal justice reform, climate change. There is also concern about militarism, there's concern about Israel and Palestine, and if Muslims will have their civil liberties" (Kaleem, 2019). Demonstrative of the trend, many of Hanson's longtime students and colleagues, including Bazian, supported the group Bay Area Muslims for Bernie, and when Sanders dropped out and endorsed Joe Biden, most community members followed suit.

Hanson initially shared in his community's castigation of Trump by publicly criticizing him, but he has also demonstrated a willingness to engage each successive administration in a principled nonpartisan manner (Kaleem, 2019). While engagement was questioned less during the Obama administration's tenure because the 
regime made discernable attempts to engage Muslims at public events like the annual White House iftar, the foreign policy of annexing Palestine and drone striking Muslim lands was no less problematic. Therefore, it seems to be with an even hand that back in June of 2016, when Trump was still the Republican nominee, Hanson critically remarked to $C N N$ : "He's playing a dangerous game, and a lot of lives are threatened by that type of saber-rattling. We're in an extremely volatile situation and social media has introduced an unprecedented element that we don't fully understand" (Yusuf, 2016a). Then, days after Trump won the election Hanson somberly blogged:

I still did not believe that a man, who appeared to publicly mimic a reporter's palsy, labeled Mexican migrants rapists and criminals, and, in the most explicit language, boasted of groping women, could ever be elected president-not in the United States, surely. Well, I was wrong. (Yusuf, 2016b)

As an unofficial ambassador, Hanson attempted to assuage tangible communal fears that an internment of Muslims was "highly unlikely," reassuring readers that the visible racist and violent backlash was only "a fringe element" (Yusuf, 2016b). He tried to humanize the "goodhearted people who voted for Trump" and discouraged responding with fear and despair:

Now is the time to realize that we have too much work to do, not protesting, not lighting fires, not saying, 'Trump is not my president.' He is, and that is how our system works: by accepting the results and moving on. (Yusuf, 2016b)

For Hanson, avoiding perpetual protest entailed continuing to foster interfaith consensus building with conservatives, many of whom were in the 'never Trump' camp themselves. As the scion of a notable family from Marin County, California, his immersion in the western canon, including training in medicine and various religious traditions all compliment four decades of training in Islam. Sharing both culture with conservatives and interests, such as fighting against pornography and religious persecution, Hanson's alliances culminated into stalwart conservative recommendations for his appointment on the federal commission as one of the rarely equipped Muslim intellectuals in America suited to debate policy recommendations on fundamental human rights as situated by natural law. However, Hanson's post-election blog post would be one of his last for the next several years, which would prove pivotal from a public relations perspective that necessitates maintaining channels of symmetric dialogue with communal stakeholders. In December 2016, Hanson was embroiled in the first of several successively aggregating controversies. In front of 25,000 Muslims (and several influential Christian pastors) in Toronto, progressive journalist Mehdi Hassan equated Islamophobia with racism and asked Hanson pointblank if he regretted not endorsing Black Lives Matter (BLM). By that time, discerning people, and most conservatives, had come to share concerns about the particular Marxist ideological orientation and intersectional queer identity politics that undergird the incorporated BLM platform called Black Lives Matter Foundation, Inc. and its radical calls for the destruction of heteronormativity and the nuclear family, as well as its antagonism towards law enforcement. The situation called for the tall order of acknowledging and critiquing the prevalence of unarmed black men being terrorized by police, while simultaneously humanizing police offers and maintaining opposition to the specific agenda of Black Lives Matter, Inc. without shirking the importance of racial equality. However, whisked off of an international flight and thrust on stage by conference organizers, an exhausted Hanson seemed caught off guard by the question and blundered by responding with decontextualized racial crime statistics instead of first assuaging communal concerns with typically measured nuance. When the response lacked methodical precision, it provided an opening for detractors to call him a racist. This prompted him to deliver an apology in which he historically situated the disintegration of the black family and successive erosion of religious morality as the primary threats to black Americans. However, to ideologues invested in accusing him of dismissing structural injustices, this analysis incensed them even further. In the escalation on social media both detractors and former associates excoriated him, claiming that white privilege purportedly precluded his ability to offer objective observations on racial matters (Latif, 2018). With his intentions and decades of public service being questioned, Hanson was visibly pained and subsequently stopped blogging, and thereafter all of his administrator-run social media accounts were also closed down in early 2017. Thereafter, the dialogue between supporters and critics essentially broke down. Throughout this entire ordeal, Hanson was reductively framed as an archetypal and out of touch white male, which ostensibly made him part of the problem.

Intensifying factional disagreements in the aftermath was a lack of symmetric dialogue and access. Locating and tracing the evolution of Hanson's opinions is actually quite a challenge. For one, the transient economic infrastructure underpinning the 1990s and 2000s nascent Muslim speaking circuit resulted in disparate entities owning copyrights to popular speakers' talks and intellectual contributions. Furthermore, most of Hanson's most important statements have been made at informal conferences under the pretenses that they are to be public communal addresses, as is the case with talks he previously delivered annually in Toronto; however, recordings are rarely ever released, nor are agenda, minutes, summaries or transcripts. Therefore, when detractors debate his supporters online, there is no recourse to an official catalogue or directory of his chronicled positions. Another point of criticism is his inaccessibility to 
the wider community outside of an inner circle, which some may or may not reassess when weighing factors such as administrative demands and security concerns. Moreover, Hanson's most notable lessons have been delivered at summer retreats at global sites where attendance is contingent on a selectively screened application process and attendance fee, the videos of which sometimes appear catalogued many months or years later on a subscription-based streaming service called Deenstream with expressed copyright. Like many popular speakers, Hanson's content is pirated from the Deenstream livestream feed by unofficial accounts that subsequently flood YouTube and other platforms with small clips relabeled by uploaders with provocative titles intended to garner clicks. In the stead of internally curated and titled video clips, the pirated and mislabeled clips are regularly forwarded on social media pages, including those of Hanson's colleagues at Zaytuna College, an ambiguous public relations message softly signaling a laissez faire tolerance towards continued copyright infringement.

This brief situation analysis, in which abiding contestations were further obfuscated by the communicative transmission process, partially contextualizes the critical outrage expressed when the State Department named Hanson as commissioner on the Commission on Unalienable Rights in early July 2019 because critics already shared cognitive reference points for framing Hanson's recent actions within a consecutive sequence of misjudgments. Therefore, with his personal blogging ceased, no personal social media engagement, and no detectable institutional public relations tactics to preempt the community with a statement of rationale, Hanson's detractors consequentially produced numerous critiques during July and August of 2019 that formulated a perceptible media consensus that stood essentially unchallenged thereafter. Furthermore, Hanson declined numerous offers to comment with mainstream outlets seeking clarification, leaving guidance for interested community members in short supply.

\section{Methodology and Data}

For many, Edward R. Murrow's 1954 condemnation of Senator Joseph McCarthy's allegation that communists and Soviet spies had infiltrated government and industry serves as a historical marker, a moment when morally compelled objective observers pivoted out of journalistic descriptivism into morally conscientious prescriptivism. Situating political media history, David Mindich likens the ascendancy of the Trump administration to a Murrow moment in part of his larger criticism that American audiences are increasingly less informed voters who make decisions based on slogans and that voicing a subjective opinion on the administration can severely polarize a person's public persona, thereby discouraging voices from exercising their freedom of expression (Mindich, 2016). A suggested heuristic for conceptualizing this phenomenon is a journalistic analysis of contested dialogues about the Vietnam War. Daniel Hallin (1986) utilized media framing to describe how communities receive information, dividing public opinion into three parts within the opinion corridor: the sphere of consensus where writers can invoke what are considered shared assumptions, the sphere of legitimate controversy that forces interlocutors to attempt editorial objectivity, and the sphere of deviance whereby interlocutors feel authorized in censoring ideas deemed beyond the pale.

In response to the formation and announcement of the Commission on Unalienable Rights in the summer of 2019, hundreds of opinion editorial articles were published in the mainstream press. I read through them in search of an overlap in themes, and then I limited the data collection to 100 articles published within the 90-day media cycle surrounding the July 8, 2019 announcement of the commission. The overwhelming majority of articles published took a very critical stance, the themes ranging from critiques against the formation of the panel itself, to numerous allegations against its members and their stances on issues like abortion, with many going as far as alleging that the panel had an ulterior motive to advance Christian fundamentalism at the policy level. As these themes dominated the corpus, I included articles in the data collection from The Washington Post, Politico, The New York Times, Reuters, The Wall Street Journal, The New Yorker, CNN, The Los Angeles Times, The Nation, The Guardian, Chronicle, Salon, Al Jazeera, and several other 'mainstream' outlets that specifically mention Hanson and generally fall under the center-left and far-left political rubric. Then, in attempting to balance the data, I ran searches for articles about the commission that praised its efforts, and found several articles published at conservative, religious and libertarian outlets such as The Cato Institute. Next, I searched for articles that kept their reporting to more descriptive accounts, which led to articles from centrist perspectives published at outlets such as The Atlantic. I analyzed all of the articles and categorized the arguments into themes.

In search of a method that would provide a better opportunity for this thematic analysis to materialize I conducted a cross analysis on authors in order to verify authorial connections to the Muslim community, analyzing documented publication history in Muslim communal public spaces and platforms. From this deductive method I was able to identify 40 of the articles as being authored by public figures in the American Muslim community, all of whom mentioned the inclusion of Hanson on the commission as a primary interest in their pieces. Hanson has authored numerous books and has served as editor in chief and contributor for two peer-reviewed journals: Seasons and Renovatio. After reading his extant list of publications and then close reading the critical opinion editorials, dominant themes emerged. Among authors with links to the American Muslim community, the locus of criticism about Hanson primarily utilizes distinctly progressive political modes of argumentation almost entirely devoid of theologi- 
cal rationale or engagement with his publication trackrecord. This finding reinforced the balkanization hypothesis of discourse breaking down within communities. Coincidentally, these 40 articles were shared and discussed widely on social media platforms and private WhatsApp groups in the Muslim community (in contrast to the other 60), indicating an inner-communal impact that has remained difficult to measure. As media researchers point out, forums for debate are governed by their own type of logic, sometimes utilized as selfperceived correctives pushing back against narratives in the traditional media space deemed problematic (Holt, 2018). There is scant research investigating such discord in the American Muslim community from a media perspective, but this event was a clear example of inner communal discord (fitnah) becoming publicly elicited.

Therefore, using Hallin's sphere of deviance after identifying the site of contestation to the widely shared opinion editorials, I divided the 100 articles thematically into four distinct categories.

The first category comprises mainstream publications contesting the commission's mandate to examine the root bases of inalienable rights in order to advise policymakers at the Bureau of Democracy, Human Rights and Labor Affairs. Critics at progressive publications like The Washington Post fear the commission's language is code for curtailing progressive advances, or in the words of Politico a "counterweight to an expansive liberal view on human rights" (Toosi, 2019). Attempting to assuage such fears, Chairperson Mary Ann Glendon responded to these charges in a podcast, stating: "I would suggest that they read the charter of the commission...instead of indulging in wild speculation.....t's an independent study group and it has been directed to focus on principles and not policies or specific issues" (Howell, 2019). This category contains broader criticism, including some of Hanson, not as central to the discussion, but as one in a group of purportedly threatening religious caricatures; as feminist publication Ms. Magazine charges: "Shaykh Hamza Yusuf Hanson sees marriage equality for LGBTIQ people as a sign of the End Times" (Susskind \& Stern, 2019).

The second category comprises conservative and libertarian praise for the commission's initiative, such as an article by The Cato Institute suggesting: "If this new commission can refocus America's human rights thinking and policy on America's first principles, grounded in our unalienable natural rights, the implications are far reaching, not only for the rest of the world but for America itself" (Pilon, 2019). Within this category there are many positive allusions to the inclusion of a Muslim. Robert George, one of the most prominent and influential Catholics in the United States, is a persisting advocate for Hanson's inclusion, and by directive of the Second Vatican Council's interfaith initiative Nostra Aetate George (2019) similarly fosters dialogue on shared prerogatives:

It has been my privilege and joy to work with Muslims...in defending human life in all stages and conditions, beginning with child in the womb; in securing religious freedom for people of all faiths; in protecting refugees from persecution and terror; in opposing pornography and human trafficking; and in upholding marriage as the union of husband and wife.

Another influential Catholic leader, Thomas S. Hibbs (2020), praises Hanson's thought in The Dallas Morning News: "Such a conception of religion, education and tradition may well provide a salutary counter not only to much of contemporary Islamic thought and practice; it is also an alternative to tribalistic trends in advanced Western culture." The smaller third category comprises several journalistically descriptive reports on Hanson's inclusion on the commission, such as Emma Green's (2017) piece in The Atlantic titled "Muslim Americans Are United by Trump-and Divided by Race." However, the fourth category comprises editorial polemics and critical pieces classified as cyber shūrā, dissenting statements that can be attributed to public figures in the American Muslim community who can be held accountable for their public remarks (Latif, 2018). I isolate this fourth category of approximately 40 articles for closer analysis based on their critical discourse modes. The overly descriptive nature of this method is a shortcoming, while simultaneously a benefit in its ability to isolate thematic sentiment across a spectrum of articles.

\section{Cyber Shūrā: American Muslim Opinion Editorials}

Close reading of the opinion editorials reveals longstanding embedded contestations about communal chronologies and scaffolded issues of disputation. One stretches back to when Hanson was summoned to advise the White House immediately after 9/11. Hanson deliberately spent his few minutes in the Oval Office highlighting essential verses from the Quran and imploring President George W. Bush not to launch an international war in retaliation to the acts of vigilantes. However, on the way out, Hanson excoriated the tentatively titled investigation 'Operation Infinite Justice' as blasphemous, to which Bush responded by immediately changing the name, and later, the entire scope from investigation to full-scale invasion, which infamously destroyed untold numbers of lives in Iraq and the wider region. Despite the exchange being a well-documented saga in American history, some of Hanson's detractors have falsely alleged that Hanson endorsed the actual invasion of Iraq on the mere condition of Bush's name change. Hanson later acknowledged that simply engaging the president irreparably damaged his reputation and opened the door to endless criticism and libel. This danger, of being framed as a 'moderate Muslim' caricature still looms. It has had an impact on his accessibility thereafter, as Genieve Abdo notes in her monograph on the rare occasion of being granted interview access at his California home: "Hamza Yusuf felt he had been misquoted everywhere-in newspapers, on television, and on the Internet-sometimes deliberately" 
(Abdo, 2007, p. 13). All of this communally contested history is thematically embedded into the critical pieces, often intertwined with a critique of Hanson's long-standing affiliation with the United Arab Emirates (UAE), a country where he studied on scholarship in the early 1980s. A congressional policy paper outlines the UAE's global political conflicts, which are particularly upsetting to many American Muslims, not only because of United Statesbacked UAE military involvement in countries like Yemen, but also for its publication of terror lists implicating mainstream Muslim charitable institutions in the same breath as bonified terror groups (Katzman, 2019). Furthermore, in 2018 Hanson told an interviewer at an interfaith conference in the UAE: "The Emirates, inside the country, this is a country committed to tolerance" (5Pillars, 2018). Despite what seemed like an attempt to qualify praise of the country with conditional intonation signaling an exclusion of its foreign policy, a transcription of the quote went viral and he was widely denounced on social media for the statement. Another uniting theme in the critiques is solidarity in resistance to Executive Order 13769 (Trump, 2017), titled "Protecting the Nation from Foreign Terrorist Entry into the United States," which is also known colloquially as "The Muslim Ban." Also inextricably linked to race and ethnicity, Georgetown University has produced research on the ban's flaws, such as how it cites anti-Muslim conspiracy theories for justification in banning nationals from several Muslim-majority countries while ignoring how the United States has intervened militarily or otherwise in the banned countries "directly creating, or facilitating the conditions that have led to violence and political instability" (Şekerci \& Crnkovich, 2019). For some Muslims, the ban is not a priority issue. But for others, engaging the administration that has implemented several iterations of the ban is beyond the pale.

Keeping the outrage these related issues engender in perspective therefore contextualizes the unfiltered indignation expressed in some online reactions by public figures, many of whom Hanson has prior associations to such as Yale professor Zareena Grewal (2019) who Tweets: "If you are willing to defend Hamza Yusuf's new low, aligning with the Trump administration as an advisor, you're no friend of mine." Similarly outraged, professor Ovamir Anjum posts on Facebook: "For nearly twenty years I bit my tongue and have not publicly ridiculed him, thinking that he is a foolish, egotistic, but harmless preacher. I was wrong" (Anjum, 2019). Commenting on the post, Imran Muneer, host of the The Mad Mamluks podcast says: "Everyone kept turning a blind eye to it and giving him the benefit of doubt. No more. Insha'allah (God willing)" (Anjum, 2019). These public comments on social media give context to the type of often unrestrained ire displayed in the 40 articles that specifically critique Hanson. For instance, Professor Maha Hilal's editorial (2019) on Al Jazeera provocatively titled "It's Time for Muslim Americans to Condemn Hamza Yusuf" mixes in thematic critique of Hanson's affiliation to the UAE.
Her ideological perspective in concluding that the commission is "clearly designed to enable anti-black, antiwomen, Islamophobic and xenophobic policy decisions" as well as her labeling Hanson a 'cis white male' is indicative of the intersectional ideologies and languages used to disrupt objective and administrable descriptions of people's sex markers. However, pivoting into perhaps legally libelous territory Hilal repeats the slanderous claim that Hanson "met President George W. Bush and endorsed his decision to launch a military campaign against terrorism" (Hilal, 2019). The same defamation appears in Sam Hamad's (2019) piece in The New Arab, who charges "he was the only Muslim to essentially endorse George W. Bush's criminal, murderous and generally devastating War on Terror." In addition, Hamad similarly assumes the intersectional stance of accusing the commission of having an ulterior motive "to reshape the definition of 'unalienable rights' along the lines of Trump's alt-right agenda, with LGBT rights and women's reproductive rights obvious targets" (Hamad, 2019). English language Arab media sites, especially those editorially opposed to the UAE, increasingly use similar ideological language.

While malevolent attacks coalesce into the larger body of criticism, the less overtly polemical pieces bring up salient points while avoiding much of the ideological language. For instance, they give consideration to a range of issues such as the consequences of disengaging with the government for four to eight-year administrative periods, in contrast to having an American Muslim presence in rooms where impactful policy recommendations are being discussed. These critiques are embodied by Professor Khaled Beydoun's (2019) piece, “For American Muslims, Hamza Yusuf's Endorsement of Trump Is One Step Too Far," which begins by acknowledging Hanson's human rights advocacy "demonstrated time and again" for Yemen, Syria and the Rohingya before referencing Hanson's statements on Black Lives Matter in Toronto as one of the "recent precedents" that "signal a clear trajectory...toward power and away from the people." Beydoun then proceeds to pragmatically contextualize his interpretation of Hanson's perceived shift in approach:

Yusuf the spiritual and political firebrand is no more. And too many within the Muslim American and global milieus still latch onto a version and vision of Yusuf that has been replaced by a man who views power, and the most vile stewards of it, as useful channels toward improving the humanitarian conditions of Muslims around the world. (Beydoun, 2019)

Similarly, journalist Azad Essa's (2019) piece "Hamza Yusuf and the Struggle for the Soul of Western Islam" also offers initial praise before noting perplexedly: "The man who once suggested Muslims were wary of any scholar too close to the government is now working with Trump, and seen by some as an Emirati stooge." Additionally, 
Daniel Haqiqatjou (2019) begins his critique by prefacing his empathy with Hanson's supporters: "I get it. I used to defend Sh Hamza Yusuf for certain things as well....When there is a repeated pattern of statements and associations, we are left no choice but to revisit prior assumptions."

Close analysis of this set of articles suggests that it is unlike categories 1, 2 and 3, in that minimal treatment is allocated to addressing the human rights agenda on the commission's terms as evidenced by scarce referencing to any publications of its commissioners, the open commission meetings, agendas, minutes, or the charter itself, seemingly affirming the hypothesis of balkanization through the formation of filter bubbles. However, it is similar to the bulk of criticism in that the pieces largely avoid using the truth claims of Islam or its concomitant scripture to establish or refute points. The issues rest squarely on political assumptions. Criticisms of Hanson voiced by prominent North American Muslim professors Mohammad Fadel, Jonathan A. C. Brown, and Joseph Lumbard, as well as censure coming from religious scholars such as Suhaib Webb and Shadee EIMasri, therefore, stand out as outliers in their select use of religious justifications in comparison to the data set. Despite the outliers, the dialogue between critics and supporters largely remains fixated on the optics of what is reduced at times to "joining Trump's human rights panel" (Farooq, 2019). However, resisting the impulse to frame things so simplistically hinges on a level of nuance that perhaps cannot be expected of non-specialists on social media, because while the connection to Trump was technically indirect, since the commission was comprised of civil servants under an independent mandate, thematic discourse markers consistently focus on the fact that it reported to the Department of State, and was led by a member of the Cabinet who was nominated by Trump.

\section{Conclusions}

This article has tried to note that various factors impact freedom of expression, from racial and ethnic identity markers, to contested chronologies, to ideology and recent information bias, all of which play roles in determining who has what license. Opinionated people have always met fierce opposition. However, when race and identity politics constitute such aggravating factors in the American Muslim community's critical subconsciousness and its widespread opposition to an administration, a Muslim scholar's identity markers can become over emphasized in public scrutiny. Moreover, within the data corpus some appear merely fixated on settling old scores, while others seem to loathe why a 'cis white man' gets to represent Muslims in circles of power and in dominant culture. Emphasis on such mediocre critiques, however, obfuscates attention away from judicious dialogues that raise legitimate points. In this case, after the publication of successive critical periodicals Hanson's Wikipedia entry was edited to read "controversial American Islamic scholar." However, when editorially contested by supporters, Wikipedia struggled to substantiate the label, and "controversial" was just as easily edited out ("Hamza Yusuf," n.d.). As a mirror of deconstructionist culture encyclopedias function as commercial artifacts that reflect the pursuit of verifiability over truth as it is socially constructed by perennially changing discourse (Gaitano, 2016). Nevertheless, such dominant markers are still important. While criticism has a place, it often tacitly assumes that the critic knows better, and in such a vituperative climate it may have been more strategic to designate such a high-risk appointment to a Muslim intellectual who was similarly qualified, but not as pivotal to the survival of institutions. Furthermore, while beyond the scope of analysis here, thematic association suggests a wider geopolitical element to this entire episode as evidenced by periodical placement and editorial stances affiliated with UAE rival states such as Qatar (Al Jazeera) and Turkey (TRT and Maydan). Future research should investigate such links, whereas other longitudinal research should investigate whether the professed critical opinions are simply held by a handful of vocal detractors as Hanson contends, or whether they are actually more representative of the broader American Muslim community's sentiments.

Ex-United Kingdom Ambassador to Lebanon Tom Fletcher (2016) argues that it is a mistake for a public person to be absent on platforms like Twitter where one's constituents and critics are framing the debate. As a vocal critic laments, representatively, "this article was sent to Shaykh Hamza for comment at the beginning of this month, but he has not replied" (Al-Azami, 2019). However, 'punching up' genre criticism being on the increase does not necessarily indicate a reasonable expectation that a commentator on metaphysics, for instance, would start appreciating the analyses of pundits and start engaging them within their preferred ideological frameworks, at their preferred venues. Moreover, the sheer number of supportive comments in social media spaces indicates significant support for Hanson abides. Nevertheless, the privation of his personal engagement on critical platforms translates into a silence thereby interpreted by critics as elitism and tonedeafness. However, the newfound visceral impertinence that characterizes criticism of communal elders heavily factors in to why many simply retreat from spaces where opposing opinions are unwelcomed, substantiating the hypothesis that online factions appear to be further balkanizing (Hampton, 2014).

To the extent that a researcher can minimize the speculative nature of understanding a person's rationale or philosophy by gleaning it from uncatalogued public statements, there is a wider context for questioning social media engagement besides the time it demands. For instance, Shoshana Zuboff's (2019) indictment of surveillance capitalism gives us pause about accepting the arrangements society has with its social media overlords. Authoritarian countries like China, acknowledging the 
power of these platforms and their impacts on expression, choose to bring them under the nexus of the state, while liberal democracies like the United States still allow private citizens in Silicon Valley to amass and wield their controlling power. In fact, in early July 2019, Hanson told Malaysian media figure Sharaad Kuttan (2019) he would advise China if given the chance specifically because of their abuse of religious minorities like the Uighurs. There are also indications that Hanson has acknowledged that internal clip curation and administrator-run social media accounts must be institutional priorities. There was a recorded public exchange at Zaytuna College in August of 2019 in which Hanson elaborated to a panel why it was good to have a Muslim voice in the (commission) room for "countervailence" considering "the wretched track record" of the Trump administration, adding more insight to his approach, although video of the dialogue was not published until October 27, 2019, by which time the public relations sequence initiated by his adversaries had already taken effect (Yusuf, 2019). In conclusion, as the community balkanizes, the best strategy for symmetrically engaging governments and critics remains an open question. This brief analysis ends, therefore, by recommending further exploration of the synergizing epistemic intersection between progressive intersectional discourses, Arab media, and political Islamist discourses, which have conventionally been at odds, and now appear to be coalescing on selective consensus building and cancellation.

\section{Acknowledgments}

I am grateful to the reviewers for their feedback. I would further like to acknowledge those who have patiently enriched my understanding of this nexus of issues more intimately, filling in so much invaluable communal chronology.

\section{Conflict of Interests}

The author declares no conflict of interests.

\section{References}

5PillarsUK. [5PillarsUK]. (2018, December 7). The prominent American scholar, Shaykh.

@Hamza Yusuf, described the United Arab Emirates as a "country committed to tolerance" [Tweet]. Retrieved from https://twitter.com/5pillarsuk/status/ 1070820373678186497 ?lang=en

Abdo, G. (2007). Mecca and main street. Oxford: Oxford University Press.

Al-Azami, U. (2019, September 15). Shaykh Hamza Yusuf and the question of rebellion in the Islamic tradition. Muslim Matters. Retrieved from https:// muslimmatters.org/2019/09/15/shaykh-hamzayusuf-and-the-question-of-rebellion-in-the-islamictradition
Anjum, O. [Ovamir Anjum]. (2019, September 11). Twenty years ago when I first met HY. [Facebook status update]. Retrieved from https://www.facebook. com/permalink.php?story_fbid $=1010977551410325$ $7 \& i d=8642218$

Beydoun, K. (2019, July 22). For American Muslims, Hamza Yusuf's endorsement of Trump is one step too far. Al Araby. Retrieved from https://www.alaraby. co.uk/english/Comment/2019/7/22/Hamza-Yusufsendorsement-of-Trump-a-step-too-far

Borchers, C. (2015, December 7). Here are those Muslim 'sports heroes' President Obama is talking about. The Washington Post. Retrieved from https://www.washingtonpost.com/news/the-fix/ wp/2015/12/07/here-are-those-muslim-americansports-heroes-president-obama-is-talking-about

Bulliet, R. (2004). The case for Islamo-Christian civilization. New York, NY: Columbia University Press.

Chopra, G. (Director). (2018). Shut up and dribble [Motion Picture]. USA: Showtime.

Daniels, T. P. (2019). Blackamerican Muslim scholars and leaders in New York City: Sidelining Islamophobia and misrepresentations. American Journal of Islamic Sciences, 36(4), 61-88.

Essa, A. (2019, August 8). Hamza Yusuf and the struggle for the soul of western Islam. Middle East Eye. Retrieved from https://www.middleeasteye.net/ big-story/hamza-yusuf-and-struggle-soul-westernislam

Farooq, U. (2019, July 9). US Muslim scholar joins Trump's human rights panel. $A A$. Retrieved from https://www.aa.com.tr/en/americas/us-muslimscholar-joins-trumps-human-rights-panel/1527283

Fish, S. (2001). How Milton works. Boston, MA: Belknap Press.

Fletcher, T. (2016). The naked diplomat: Power and statecraft in the digital age. London: William Collins.

Gaitano, N. (2016). Is Wikipedia the new encyclopedia of post-modern times? Church, Communication and Culture, 1(1), 166-168.

George, R. P. (2019, October 4). Muslims and Christians must unite against hate. America Magazine. Retrieved from https://www.americamagazine.org/ faith/2019/10/04/muslims-and-christians-mustunite-against-hate

Green, E. (2017, March 11). Muslim Americans are united by Trump and divided by race. The Atlantic. Retrieved from https://www.theatlantic.com/politics/archive/ 2017/03/muslim-americans-race/519282

Grewal, Z. [ZareenaGrewal]. (2019, July 9). If you are willing to defend Hamza Yusuf's new low, aligning with the Trump administration as an advisor, you're no friend of mine [Tweet]. Retrieved from https:// twitter.com/ZareenaGrewal/status/11483553981451 01824

Hallin, D. C. (1986). The uncensored war: The Mediai and Vietnam. Berkeley, CA: University of California Press. Hamad, S. (2019, July 17). Hamza Yusuf is not your friend. 
The New Arab. Retrieved from https://www.alaraby. co.uk/english/comment/2019/7/17/hamza-yusuf-isnot-your-friend

Hampton, K. (2014, August 24). Social media and the 'spiral of silence.' Pew Research Center. Retrieved from https://www.pewresearch.org/internet/2014/ 08/26/social-media-and-the-spiral-of-silence

Hamza Yusuf. (n.d.). Wikipedia. Retrieved from https:// en.wikipedia.org/wiki/Hamza_Yusuf

Hanson, H. Y. (2017, September 26). 2017 templeton prize ceremony for Dr. Alvin Plantinga [Video file]. Retrieved from https://www.youtube.com/watch? $\mathrm{v}=\mathrm{uOJJOE} \_$LPCA

Haqiqatjou, D. (2019, September 11). Are supporting and siding with tyrants Halal in Islam, Sh Hamza Yusuf? Muslim Skeptic. Retrieved from https:// muslimskeptic.com/2019/09/11/are-supportingand-siding-with-tyrants-halal-in-islam-sh-hamzayusuf

Hasan, I. (2019, September 3). Dave Chappelle's Sticks \& Stones rated low on Rotten Tomatoes. Newsweek. Retrieved from https://www.newsweek.com/davechappelles-netflix-special-sticks-stones-rated-zeropercent-rotten-tomatoes-1457458

Hibbs, T. S. (2020, February 23). In America, Islamic intellectualism is enjoying a liberal revival. Dallas News. Retrieved from https://www.dallasnews.com/ opinion/commentary/2020/02/23/in-americaislamic-intellectualism-is-enjoying-a-liberal-revival

Hilal, M. (2019, July 15). It's time for Muslim Americans to condemn Hamza Yusuf. Al Jazeera. Retrieved from https://www.aljazeera.com/indepth/opinion/ time-muslim-americans-condemn-hamza-yusuf190715130254222.html

Holt, K. (2018). Alternative media and the notion of antisystemness: Towards an analytical framework. Media and Communication, 6(4), 49-57.

Howell, J. (2019, August 3). The lawfare podcast: Mary Ann Glendon on unalienable rights. Lawfare. Retrieved from https://www.lawfareblog.com/lawfarepodcast-mary-ann-glendon-unalienable-rights

Jackson, S. (2005). Islam and the Blackamerican. Oxford: Oxford.

Jackson, S. (2009). Islam and the problem with Black suffering. Oxford: Oxford.

Kaleem, J. (2019, September 22). Why many Muslims treat Bernie Sanders like a rock star. Los Angeles Times. Retrieved from https://www.latimes.com/ politics/story/2019-09-20/bernie-sanders-muslimvoters-2020

Katzman, K. (2019). The United Arab Emirates: Issues for U.S. policy. Washington, DC: Congressional Research Service. Retrieved from https://www.justice. gov/eoir/page/file/1134191/download

Kuttan, S. (2019, July 1). Let's talk with Sharaad Kuttan (episode 250) [Video file] Retrieved from http://www.astroawani.com/video-malaysia/letstalk-sharaad-kuttan-episode-250-482031
Latif, J. (2018). Muslim American cyber contestations between scholars and activists debating racism, Islamophobia and Black Lives Matter. Journal of Religion, Media and Digital Culture, 7(1). https://doi.org/ 10.1163/25888099-00701005

Lipka, M. (2017). Muslims and Islam: Key findings in the U.S. and around the world. Washington, DC: Pew Research Center.

Milani, A. (2014, April 25). Thomas Jefferson was a Muslim. New Republic. Retrieved from https:// newrepublic.com/article/146350/presidentislamophobe

Mindich, D. (2016, July 15). For journalists covering Trump, a Murrow moment. Columbia Journalism Review. Retrieved from https://www.cjr.org/analysis/ trump_inspires_murrow_moment_for_journalism. php

Mogahed, D., \& Chouhoud, Y. (2017). American Muslim poll 2017: Muslims at the crossroads. Washington, DC: Institute for Social Policy and Understanding.

Mullan, J. (2001, August 4). Satanic majesties. The Guardian. Retrieved from https://www.theguardian. com/books/2001/aug/04/classics.highereducation

Pilon, R. (2019, May 31). Natural rights vs. human rights. Cato Institute. Retrieved from https://www.cato.org/ blog/natural-rights-vs-human-rights-statedepartments-new-commission-unalienable-rights

Şekerci, K. G., \& Crnkovich, E. (2019). The Muslim bans. Washington, DC: The Bridge Initiative.

Shaikh, A. (2019, August 30). Sherman Jackson, CVE, UAE and some questions. Muslim Matters. Retrieved from https://muslimmatters.org/2019/08/ 29/sherman-jackson-cve-uae-and-some-questions

Susskind, Y., \& Stern, J. (2019, July 26). Not a straight, white man? U.S. religious conservatives are coming for you. Ms. Magazine. Retrieved from https:// msmagazine.com/2019/07/26/not-a-straight-whiteman-u-s-religious-conservatives-are-coming-for-you

Tollefsen, C. O. (2015, July 14). Gender identity. The Public Discourse. Retrieved from https:// www.thepublicdiscourse.com/2015/07/15308/

Toosi, N. (2019, July 3). Trump's 'natural law' human rights panel readies for launch. Politico. Retrieved from https://www.politico.com/story/2019/ 07/03/human-rights-panel-1398636

Tripp, C. (2006). Islam and the moral economy. Cambridge: Cambridge University Press.

Trump, D. (2017). Executive order protecting the nation from foreign terrorist entry into the United States. (Executive Order No. 13769). Washington, DC: The White House.

Why American Muslims lean leftwards for 2020. (2019, September 22). The Economist. Retrieved from https://www.economist.com/erasmus/2019/09/22/ why-american-muslims-lean-leftwards-for-2020

Yusuf, H. (2016a, June 15). Shaykh Hamza Yusuf on gay Muslims: Scholars issue statement. Seekers Guidance. Retrieved from https://seekersguidance.org/ 
articles/prophet-muhammad/orlandostatementshaykhhamza-gay-muslims

Yusuf, H. (2016b, November 15). We shall overcome. Sandala. Retrieved from https://sandala.org/we-shallovercome
Yusuf, H. (2019, October 15). Rules of engagement [Video file]. Retrieved from https://www.youtube.

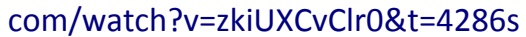

Zuboff, S. (2019). The age of surveillance capitalism. New York, NY: PublicAffairs.

\section{About the Author}

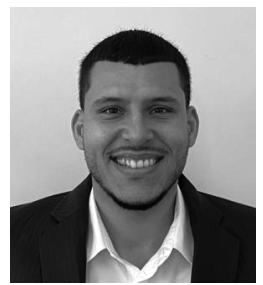

Jibril Latif is the product of two loving Californians, living in Kuwait. He has backgrounds in athletics, social sciences, and the arts and humanities. He is a contributor to various research and industry projects across the globe. 